\title{
Sistematic Study of Benzo[a]Pyrene in Coffee Samples
}

\author{
Elza S. G. Badolato, ${ }^{a}$ Maristela S. Martins, ${ }^{*, a}$ Sabria Aued-Pimentel, ${ }^{a}$ Janete Alaburda, ${ }^{a}$ \\ Edna E. Kumagai, ${ }^{a}$ Gisleine G. Baptista ${ }^{a}$ and Amaury Rosenthal ${ }^{b}$ \\ ${ }^{a}$ Divisão de Bromatologia e Química, Instituto Adolfo Lutz, CP 1873, 01069-790 São Paulo-SP, Brazil \\ ${ }^{b}$ Embrapa Agroindústria de Alimentos, Av. das Américas, 29.501, 23020-470 Rio de Janeiro-RJ, Brazil
}

\begin{abstract}
Neste trabalho foi avaliado e otimizado um método para extração e quantificação de benzo[a]pireno (B[a]P) em amostras de café das espécies conillon (Coffea canephora) e arabica (Coffea arabica), verde e torrado em pó. A influência do processo de torração na formação do B[a]P também foi estudada. Estas amostras foram extraídas com acetona, seguidas por saponificação, extração com ciclohexano e purificação em coluna de silica-gel. A quantificação foi feita por CLAE por eluição isocrática em fase reversa com detector de fluorescência. Os limites de detecção e quantificação foram de 0,03 e $0,10 \mu \mathrm{g} \mathrm{kg}^{-1}$ respectivamente. O intervalo de recuperação foi de 76 a $116 \%$ para concentrações entre 1,00 e $3,00 \mu \mathrm{g} \mathrm{kg}^{-1}$. Os resultados obtidos para o $\mathrm{B}[\mathrm{a}] \mathrm{P}$ foram de $0,47 \mathrm{a} 12,5 \mu \mathrm{g}$ $\mathrm{kg}^{-1}$ para amostras de café em pó torradas, e não foi detectado a presença de B[a]P em amostras de café verde. Portanto, o controle dos parâmetros de torração é fundamental na obtenção de um produto de boa qualidade, sem prejuízos à saúde da população.
\end{abstract}

A method for extracting and quantifying benzo[a]pyrene (B[a]P) was evaluated and improved for samples of green and roasted ground Arabica (Coffea arabica) and Conillon (Coffea canephora) Brazilian coffees. The influence of the roasting process in $\mathrm{B}[\mathrm{a}] \mathrm{P}$ formation was considered too. These samples were extracted with acetone, followed by saponification and cyclohexane extraction. The extracts were cleaned by chromatography on a silica-gel. The quantification was done by HPLC with reversed-phase and fluorescence detection under isocratic conditions. The detection and quantification limits were $0.03 \mu \mathrm{g} \mathrm{kg}^{-1}$ and $0.10 \mu \mathrm{g} \mathrm{kg}^{-1}$, respectively. The recovery ranged from 76 to $116 \%$ for concentrations between 1.00 and $3.00 \mu \mathrm{g} \mathrm{kg}^{-1}$. The values obtained for B[a]P concentrations were from 0.47 to $12.5 \mu \mathrm{g} \mathrm{kg}^{-1}$ for samples of ground roasted coffee. B[a]P was absent in the green coffee samples. The control of the roasting parameters is fundamental for obtaining a good quality product.

Keywords: benzo[a]pyrene, polycyclic aromatic hydrocarbons, coffee, HPLC analysis

\section{Introduction}

Polycyclic aromatic hydrocarbons (PAHs) are classified as a chemical group of more than one hundred different organic compounds containing two or more condensed aromatic rings. They are formed by the incomplete combustion or thermal decomposition (pyrolysis) of organic material and are widely distributed in the environment. ${ }^{1}$ The quantity and composition of the PAHs produced are closely related to the reaction conditions, temperature and raw material characteristics. ${ }^{2}$

Many of them, including benzo[a]pyrene (B[a]P), are carcinogenic and mutagenic in experimental animals and these compounds may be regarded as potentially genotoxic and carcinogenic to humans. ${ }^{3-6}$ Benzo[a]pyrene is the most

*e-mail: mmartins@ial.sp.gov.br commonly studied and measured PAH compound and has served as an indicator of total PAHs contamination. ${ }^{7,8}$

Several studies have estimated that dietary intake represents around $97 \%$ of the total daily non-occupational human exposure to $\mathrm{B}[\mathrm{a}] \mathrm{P}$ and have indicated that of all possible means of human exposure to PAHs, ingestion is the most predominant. ${ }^{9,10}$ Due to the difficulty of extrapolating toxicity data from animals to humans, although the carcinogenic properties of PAHs and B[a]P have been demonstrated, it has not yet been possible to establish which $\mathrm{PAH}$ and $\mathrm{B}[\mathrm{a}] \mathrm{P}$ rates constitute a health risk. ${ }^{11}$ However, the food contamination studies are included in the JECFA (Joint FAO/WHO Expert Committee on Food Additives) priority list. ${ }^{12}$ In addition, European Commission has just published the Regulation (EC) No. 208/2005, establishing maximum level of benzo[a]pyrene in some foods. ${ }^{13}$ 
Different ways of $\mathrm{B}[\mathrm{a}] \mathrm{P}$ contamination in food have been suggested, such as the process of drying seeds, cooking, and roasting, among others. In the specific case of coffee samples, the drying and roasting beans steps may be responsible for $\mathrm{B}[\mathrm{a}] \mathrm{P}$ contamination. The concentrations of $\mathrm{B}[\mathrm{a}] \mathrm{P}$ in roasted coffee stayed in the range of $0.3-15.8 \mu \mathrm{g} \mathrm{kg}^{-1} \cdot{ }^{14-16}$

$\mathrm{B}[\mathrm{a}] \mathrm{P}$ is chemically inert and hydrophobic, ${ }^{17}$ however, its solubility in aqueous solution may be increased by the presence of caffeine, causing caffeine-B[a]P complex formation. ${ }^{14,18}$ This complex may be responsible for the occurrence of $\mathrm{B}[\mathrm{a}] \mathrm{P}$ in coffee brew.

The objective of this research was to develop an extracting and quantifying $\mathrm{B}[\mathrm{a}] \mathrm{P}$ method in green and roasted ground coffees, including the evaluation of the influence of the roasting process in $\mathrm{B}[\mathrm{a}] \mathrm{P}$ formation.

\section{Experimental}

\section{Samples}

Twenty-four coffee samples were analyzed: four samples of Conillon and twenty of Arabic coffees. Different kinds of green and roasted ground coffees were selected and analyzed: Conillon, Arabica dura, Arabica mole, Arabica rio, Arabica riada, Arabica rio zona, with American, conventional and express roasting. The coffee samples were specially roasted at Embrapa/CTAA for this experiment. The end of the roasting process was determined by visual and instrumental measure of colour parameters using the Hunter L a b system.

\section{Chemicals and reagents}

The following reagents were used for $\mathrm{B}[\mathrm{a}] \mathrm{P}$ extraction: silica Gel 60 - particle 0.063-0.200 mm (70-230 mesh ASTM), potassium hydroxide (pellets), anhydrous sodium sulphate, cyclohexane, acetone, and methanol. These reagents were analytical grade (Merck). For liquid chromatography, HPLC grade acetonitrile (Merck) and water from the Milli-Q system was used; both were filtered through $0.45 \mu \mathrm{m}$ Millipore membranes of $47 \mathrm{~mm}$ diameter before use. The benzo[a]pyrene standard (Sigma) had a minimum of $97 \%$ purity.

\section{Extraction and clean-up}

The extraction and clean-up procedures were adapted from those described by Kruijf et al. ${ }^{7}$ according to the steps described in Scheme 1. A $20 \mathrm{~g}$ portion of ground homogenized coffee samples were extracted in a Soxhlet apparatus over a period of 6 hours with $250 \mathrm{~mL}$ of acetone. The solvent was removed under reduced pressure at $40{ }^{\circ} \mathrm{C}$. The residue was saponified with $1.4 \mathrm{~g}$ of potassium hydroxide in $50 \mathrm{~mL}$ of methanol-water $(9: 1$, v/v) under reflux. After completion the saponification (30 minutes), $120 \mathrm{~mL}$ of distilled water was added slowly through a condenser. The mixture was transferred to a separatory funnel and was first shaken with $40 \mathrm{~mL}$ of cyclohexane for 2 minutes. After separating the layers, the aqueous layer was twice extracted with fresh portions of $30 \mathrm{~mL}$ cyclohexane for 2 minutes. The combined cyclohexane extracts were dried over $50 \mathrm{~g}$ of anhydrous sodium sulphate prewashed with $20 \mathrm{~mL}$ of cyclohexane, then concentrated in a rotary evaporator at $40{ }^{\circ} \mathrm{C}$ to approximately $4 \mathrm{~mL}$.

The concentrated extract was applied to the top of a 5 $\mathrm{g}$ silicagel column, which was deactivated with water $15 \%$ $(\mathrm{m} / \mathrm{m})$. The column was prewashed with $20 \mathrm{~mL}$ of cyclohexane, and eluted with $100 \mathrm{~mL}$ cyclohexane. The first $10 \mathrm{~mL}$ of cyclohexane eluate was discarded; the rest of the eluate was collected and concentrated in a rotary evaporator at $40{ }^{\circ} \mathrm{C}$ to about $4 \mathrm{~mL}$ and dried using nitrogen stream and gentle heating. The residue was dissolved in 3 $\mathrm{mL}$ of HPLC acetonitrile, filtered through a nylon acrodisc, and analysed by HPLC.

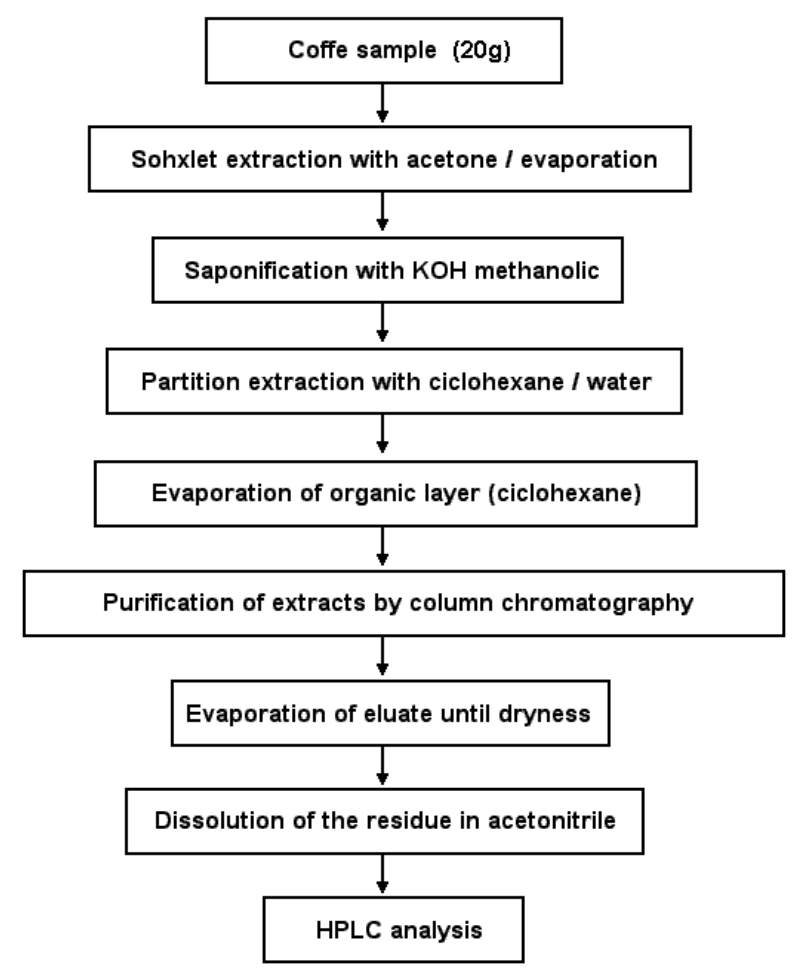

Scheme 1. Schematic representation of experimental extraction and purification procedures to obtain benzo[a]pyrene extracts from green and roasted coffee samples. 


\section{HPLC analysis}

The benzo[a]pyrene extract from these samples was quantified by a HPLC Shimadzu device coupled with a fluorescence detector. Separations were achieved on a 5 $\mu \mathrm{m}$ Lichrosphere 100 RP18 (4.6 mm i.d. by $15 \mathrm{~cm}$ length) operated at room temperature. The mobile phase acetonitrile - water (80:20, v/v) was used at a flow rate of

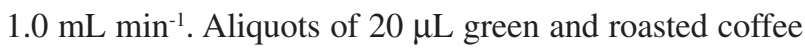
sample extracts were injected in the HPLC column. The fluorescence detector was operated with an excitation wavelength at $295 \mathrm{~nm}$ and the measurement at $405 \mathrm{~nm}$. The chromatographic process was done in 15 minutes.

$\mathrm{B}[\mathrm{a}] \mathrm{P}$ was identified by comparing the time retentions of standard solutions and samples under the same experimental conditions of the chromatography analysis immediately after spiking the samples. Quantification was performed by comparison samples peak areas with those obtained using standard solutions in a calibration curve.

\section{Analytical quality control}

In order to verify the accuracy and precision of the analytical procedure, recovery experiments were carried out by spiking the starting solvents $(\mathrm{n}=4)$ with $2 \mu \mathrm{g}$ $\mathrm{kg}^{-1}$ (ppb) of $\mathrm{B}[\mathrm{a}] \mathrm{P}$ and the selected sample of Conillon conventionally roasted $(\mathrm{n}=3)$ with 1.00 to $3.00 \mu \mathrm{g} \mathrm{kg}^{-1}$ (ppb) of B[a]P. This coffee sample was chosen because it showed the lowest contamination of $\mathrm{B}[\mathrm{a}] \mathrm{P}$.
The detection and quantification limits were defined as three and ten times the noise, respectively. The noise values were determined by measuring the amplitude signal by fluorescence analysis of a blank reagent $(n=6)$. The noise value was considered to be half of the amplitude baseline signal in the retention time region. ${ }^{19}$

The ground green and roasted coffee samples were analyzed in triplicate.

\section{Results and Discussion}

The $\mathrm{B}[\mathrm{a}] \mathrm{P}$ calibration curve (linear regression) for coffee samples quantification is described by equation: fluorescence value $=8 \times 10^{7}$ [benzo[a]pyrene +0.3394 ; $\left(r^{2}=0.9993\right)$ with a linearity range from $0.10 \times 10^{-3}$ to $0.10 \mu \mathrm{g} \mathrm{mL}^{-1}$ (ppm) B[a]P.

The recovery results from the blank reagent were in the range of 100 to $105.5 \%$ (Table 1), and the recovery values of the spiked conillon conventional roasted coffee samples were found to be between 76 to $116 \%$ (Table 2). The detection and quantification limits were $0.03 \mu \mathrm{g}$ $\mathrm{kg}^{-1}$ and $0.10 \mu \mathrm{g} \mathrm{kg}^{-1}$, respectively.

All B[a]P extract determinations in green coffee samples were below detection limit. The ground roasted coffee samples stayed in the range between 0.47 to 12.5 $\mu \mathrm{g} \mathrm{kg}^{-1}$ (ppb) (Figure 1, Table 3).

The coffee samples analyzed were specially roasted for this experiment to evaluate the influence of the roasting process in the formation of benzo[a]pyrene. Different

Table 1. Recovery results to the analysis of blank reagent sample

\begin{tabular}{lccc}
\hline $\begin{array}{l}\text { Spiked B[a]P } \\
\text { concentration / }\left(\mu \mathrm{g} \mathrm{kg}^{-1}\right)\end{array}$ & $\begin{array}{c}\text { Experimental B }[\mathrm{a}] \mathrm{P} \\
\text { values } /\left(\mu \mathrm{kg}^{-1}\right)\end{array}$ & $\begin{array}{c}\text { Recovery } \\
\text { results } /(\%)\end{array}$ & $\begin{array}{c}\text { Median recovery } \\
\text { values } /(\%)\end{array}$ \\
\hline & 2.12 & 104.95 & \\
2.02 & 2.13 & 105.45 & 102.73 \\
\\
2.02 & 100.00 & 2.8 \\
\hline
\end{tabular}

Table 2. Recovery values $(n=3)$ of the spiked conventionally roasted Conillon coffee sample

\begin{tabular}{|c|c|c|c|c|}
\hline $\begin{array}{l}\text { Spiked } \mathrm{B}[\mathrm{a}] \mathrm{P} \\
\text { concentration } /\left(\mu \mathrm{g} \mathrm{kg}^{-1}\right)\end{array}$ & $\begin{array}{l}\text { Experimental } \mathrm{B}[\mathrm{a}] \mathrm{P} \\
\text { values } /\left(\mu \mathrm{g} \mathrm{kg}^{-1}\right)\end{array}$ & $\begin{array}{l}\text { Recovery } \\
\text { results / (\%) }\end{array}$ & $\begin{array}{l}\text { Median recovery } \\
\text { values / }(\%)\end{array}$ & $\mathrm{RSD} /(\%)$ \\
\hline 0 & $0.48 \pm 0.02$ & - & - & - \\
\hline 1.01 & $\begin{array}{l}1.40 \\
1.43 \\
1.71\end{array}$ & $\begin{array}{c}84 \\
87 \\
116\end{array}$ & 96 & 18 \\
\hline 2.02 & $\begin{array}{l}2.09 \\
2.50 \\
2.46\end{array}$ & $\begin{array}{l}76 \\
96 \\
94\end{array}$ & 85 & 14 \\
\hline 3.03 & $\begin{array}{l}3.96 \\
3.57 \\
3.21\end{array}$ & $\begin{array}{c}112 \\
100 \\
88\end{array}$ & 99 & 12 \\
\hline
\end{tabular}




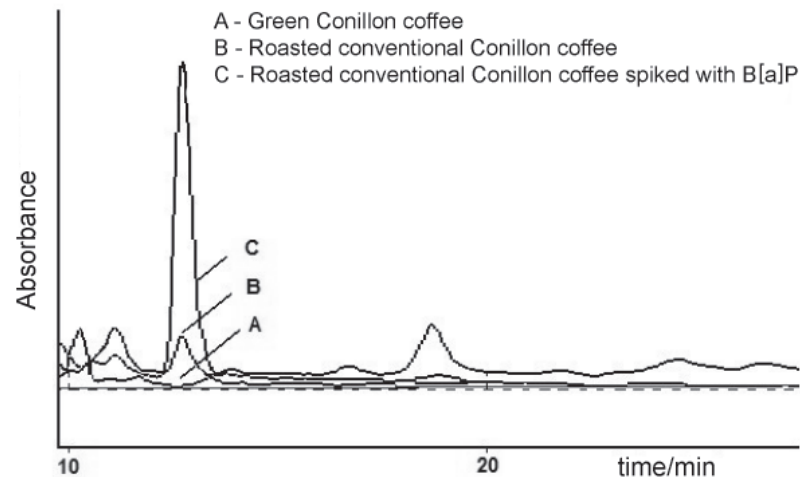

Figure 1. HPLC chromatograms with fluorescence detection of the B[a]P extracts from ground green and roasted Conillon coffee samples (conventional roasted with and without spiking).

kinds of coffees were used: Conillon, Arabica dura, Arabica mole, Arabica rio, Arabica riada, Arabica rio zona, with American, conventional and express roasting.

The extraction of $\mathrm{B}[\mathrm{a}] \mathrm{P}$ from coffee samples had been made first by Grimmer and Böhnke ${ }^{20}$ methodology modified by Lintas et al. ${ }^{21}$ However, this process was found to be time and solvent consuming and the recovery values were not as good as expected.

The method described by Kruijf et al. ${ }^{7}$ was evaluated, and applied as described originally. However, the benzo[a]pyrene extracts obtained from coffee samples using the Kruijf et al. method $^{7}$ had natural unwanted compounds, which have retention times and fluorescence absorbances similar to benzo[a]pyrene. In order to eliminate these compounds, a clean-up step using a silicagel column was added to the procedures of the experiment.

This clean-up step was essential to become the experimental conditions selective for benzo[a]pyrene, as shown in Figure 1, eliminating the unwanted compounds. In these chromatograms, the unwanted compounds were absent from the ground green, roasted and roasted spiked coffee samples during the $\mathrm{B}[\mathrm{a}] \mathrm{P}$ retention time. The recovery values had good yield.

Despite using this new clean-up step, this method should be simple, with fewer experimental steps in comparison to the others, because extraction, solvent evaporation and extract saponification can be perfomed in the same flask. This procedure permited the reduction of both experimental time and solvent quantities, minimizing analyte loss.

Detection and quantification limits were $0.03 \mu \mathrm{g} \mathrm{kg}^{-1}$ (ppb) and $0.10 \mu \mathrm{g} \mathrm{kg}^{-1}(\mathrm{ppb})$, respectively, lower than the $\mathrm{B}[\mathrm{a}] \mathrm{P}$ results from the coffee samples; the last were in the range between 0.47 to $12.5 \mu \mathrm{g} \mathrm{kg}^{-1}$ (ppb) for ground roasted coffee samples (Table 3 ). The recovery values were $76 \%$ to $116 \%$ for concentrations of 1.00 to $3.00 \mu \mathrm{g} \mathrm{kg}{ }^{-1}$ (ppb) (Table 2). These results proved that the present method is useful in $\mathrm{B}[\mathrm{a}] \mathrm{P}$ analyses in ground roasted coffee samples.

Table 3. Results of the benzo[a]pyrene extracts $\left(\mu \mathrm{g} \mathrm{kg}^{-1}\right)$ from ground green and roasted coffee samples $(\mathrm{n}=3)$

\begin{tabular}{|c|c|c|c|}
\hline Samples & Concentration / $\left(\mu \mathrm{g} \mathrm{kg}^{-1}\right)$ & Standard & $\mathrm{RSD} /(\%)$ \\
\hline green Conillon coffee & (nd) & - & - \\
\hline American roasted Conillon coffee & 3.46 & 0.12 & 3.47 \\
\hline conventional roasted Conillon coffee & 0.48 & 0.02 & 5.26 \\
\hline express roasted Conillon coffee & 2.51 & 0.36 & 14.34 \\
\hline green coffee Arabica Dura & (nd) & - & - \\
\hline American roasted Arabica Dura coffee & 1.27 & 0.06 & 4.72 \\
\hline conventional roasted Arabica Dura coffee & 0.47 & 0.03 & 6.38 \\
\hline express roasted Arabica Dura coffee & 1.87 & 0.07 & 3.74 \\
\hline green coffee Arabica Mole green coffee & (nd) & - & - \\
\hline American roasted Arabica Mole coffee & 1.40 & 0.07 & 5.00 \\
\hline convencional roasted Arabica Mole coffee & 1.55 & 0.12 & 7.74 \\
\hline express roasted Arabica Mole coffee & 1.43 & 0.05 & 3.50 \\
\hline green coffee Arabica Rio & (nd) & - & - \\
\hline American roasted Arabica Rio coffee & 2.47 & 0.11 & 4.45 \\
\hline convencional roasted Arabica Rio coffee & 1.04 & 0.03 & 2.88 \\
\hline express roasted Arabica Rio coffee & 2.25 & 0.33 & 14.67 \\
\hline green coffee Arabica Rio Zona & (nd) & - & - \\
\hline American roasted Arabica Rio Zona coffee & 2.67 & 0.19 & 7.12 \\
\hline convencional roasted Arabica Rio Zona coffee & 4.06 & 0.31 & 7.64 \\
\hline express roasted Arabica Rio Zona coffee & 2.15 & 0.01 & 0.37 \\
\hline green coffee Arabica Riada & (nd) & - & - \\
\hline American roasted Arabica Riada coffee & 12.52 & 0.64 & 5.11 \\
\hline convencional roasted Arabica Riada coffee & 4.34 & 0.14 & 3.23 \\
\hline express roasted Arabica Riada coffee & 4.49 & 0.47 & 10.47 \\
\hline
\end{tabular}

(nd) = no detected, detection limit was $0.03 \mu \mathrm{g} \mathrm{kg}^{-1}$. 
Benzo[a]pyrene was not detected in the green coffee samples. The mean recovery values for spiked samples at 0.5 and $1.0 \mu \mathrm{g} \mathrm{kg}^{-1}(\mathrm{ppb})$ were 86.0 and $91.0 \%$ with values of relative standard deviation (\% RSD) of 11 and $15 \%$, respectively.

The lowest concentration of $\mathrm{B}[\mathrm{a}] \mathrm{P}$ was found in the conventionally roasted Arabica dura coffee sample and the highest concentration in the American roasted Arabica rio zona sample.

The experimental values showed that $\mathrm{B}[\mathrm{a}] \mathrm{P}$ contamination is directly related to the kind of roasting process; $\mathrm{B}[\mathrm{a}] \mathrm{P}$ was not detected in the green coffee samples, which discards the possibility of contamination by environmental pollution, seed drying, storage etc.

Roasting process control is important to produce marketable roasted coffee; the control of the roasting parameters is fundamental to obtain a good quality product which is harmless to human health. These characteristics are necessary to guarantee competitivity and satisfactory exportation to international markets. The present methodology to verifying $\mathrm{B}[\mathrm{a}] \mathrm{P}$ contamination is adequate to evaluate all the steps in the chain production, from raw material to final product, and more specifically the roasting process, which is a critical point in the manufacturing of roasted coffee.

\section{Conclusions}

An adequate methodology for analyzing $\mathrm{B}[\mathrm{a}] \mathrm{P}$ in green and ground roasted coffee samples was studied and validated. It permits quality control of both raw material and final product destined to local and international markets.

In addition, it was verified that $\mathrm{B}[\mathrm{a}] \mathrm{P}$ contamination is due to the kind of roasting process utilized, so the choice of roasting process and control parameters are very important for the safety and final quality of roasted coffee.

\section{Acknowledgment}

The authors thank the "Programa Nacional para Pesquisa e Desenvolvimento do Café" coordinate by Embrapa/Café for supporting this study.

\section{References}

1. Lopes, W. A.; De Andrade, J. B.; Quim. Nova 1996, 19, 497.

2. Bjorseth. A.; Ramdahl, T.; Handbook of Polycyclic Aromatic Hydrocarbons: Emission Sources and Recent Progress in Analytical Chemistry ; Marcel Dekker Inc.: New York, 1985, vol. 2.

3. IARC, Monographs on the Evaluation of Carcinogenic Risk of Chemicals to Humans: Polyciclic Aromatic Compounds; IARC: France, 1983, p.32.

4. WHO/ International Programme on Chemical Safety (IPCS); Environmental Health Criteria 202, Selected Non Heterocyclic Polycyclic Aromatic Hydrocarbons; World Health Organization: Geneva, 1998.

5. http://europa.eu.int/comm/food/fs/sc/scf/out153_en.pdf, acessed in November 2005

6. ftp://ftp.fao.org/codex/ccfac37/FA37_34e.pdf, accessed in November 2005.

7. Kruijf, N; Schouten, T.; Van Der Stegen, G. H. D.; J. Agric. Food Chem. 1987, 35, 545.

8. Kazerouni, N.; Sinha, R.; Hsu, C. H.; Greenberg, A.; Othman, N.; Food Chem. Toxicol. 2001, 33, 423.

9. Phillips, D. H.; Mutat. Res. 1999, 443, 139.

10. Stavric, B.; Klassen, R.; Food Chem. Toxicol. 1994, 32, 727.

11. Moret, S.; Conte, L. S.; J. Chromatogr., A 2000, 882, 245.

12. http://www.fao.org/docrep/meeting/005/w1362e/w1362e08.htm, accessed in November 2005.

13. Commission Regulation (EC) No. 208/2005; Official Journal of the European Union 2005, L 34/3.

14. Kuratsune, M.; Hueper, W. C.; J. Natl. Cancer Inst. 1960, $2,463$.

15. Howard, J. W.; Fazio, T. A.; J. Agric. Food Chem. 1969, 17, 527.

16. Hattermer-Frey H. A, Travis, C. C.; Toxicol. Ind. Health 1991, 7, 141.

17. Camargo, M. C. R.; Toledo, M. C. F.; Cienc. Tecnol. Aliment. 2002, 22, 49.

18. Kolarovic, L.; Traitler, H.; J. Chromatogr. 1982, 237, 263.

19. Nieman, T. A.; Skoog, D. A.; Holler, F. J.; Introdução, Princípios de Análise Instrumental, $5^{\text {th }}$ ed.; Bookman: São Paulo, 2002, p.100.

20. Grimmer, G.; Böhnke, H.; J. AOAC Int. 1975, 58, 725.

21. Lintas, C.; Matthaeis, M. C.; Food Cosmet.Toxicol. 1979, 17, 325.

Received: February 23, 2006

Published on the web: July 13, 2006

FAPESP helped in meeting the publication costs of this article. 